\title{
Shifting beach wrack composition in the SW Baltic Sea and its effect on beach use
}

\author{
Florian Weinberger $^{1}$, Swantje Sundt $^{2}, \underline{\text { Nadja Staerck }}^{1}$, Christine Merk $^{3}$, Rolf Karez $^{4}$ and Katrin Rehdanz $^{2}$
}

\begin{abstract}
Beach visitors rate beach quality in large part by its appearance. Removal of natural beach litter (called beach wrack) has, therefore, high priority for beach managers in coastal areas dependent on revenues from tourism. Focusing on the German Baltic Sea coast, the amount of beach wrack has increased by a factor of approximately 3.4 between 1977 and 2012/2013. At the same time, the composition of macrophyte communities underwent a severe change from late successional stages (eelgrass and bladder wrack) toward more ephemeral communities. Correspondingly, the contribution of bladder wrack to seaweed litter alone dropped from $75 \%$ in 1977 to $18.1 \%$ today, while the contribution of ephemeral and nutrient-opportunistic seaweeds increased by a factor larger than 6.2 to approximately $44 \%$. Such seaweed opportunists could have a higher potential for olfactorial nuisance than late successional macrophytes. To test this hypothesis, odors extracted from equal amounts of nutrient-opportunistic and non-opportunistic species that had been partially degraded under equal conditions were compared in a public survey. Participants graded the smell of opportunistic species, in particular Ceramium tenuicorne, consistently as more intense and less pleasant than the odor of non-opportunistic species. The particularly high potential of Ceramium litter and the relatively lower potential of eelgrass litter for deterrence were confirmed in field experiments. We conclude that the documented compositional shift in macrophyte communities at German Baltic Sea coasts since the onset of eutrophication has caused a shift of beach wrack composition toward species with a higher potential for olfactorial deterrence, which could explain recent concerns of beach managers about beach wrack despite the limited increase of biomass in the study area.
\end{abstract}

Key Words: beach management; beach user behavior; beach wrack; coastal eutrophication; nuisance seaweed; seaweed odor

\section{INTRODUCTION}

In the Baltic Sea region, as worldwide, coastal tourism and beach recreation provide important employment opportunities and income (Haller et al. 2011; Pendleton 2007). In general, the perception of beach quality by the public is based upon appearance of the water and presence of litter pollution (Vaz et al. 2009, Williams and Barugh 2014). Beach management, therefore, usually gives high priority to the removal of any debris of anthropogenic or natural origin, typically by mechanical grooming, that causes considerable costs. For example, authorities in seaside resorts on the German Baltic Sea coast annually remove $269 \mathrm{~kg}$ litter per $\mathrm{m}$ of beach, which on average costs $38 €$ per $m$ (Mossbauer et al. 2012). The annual removal of estimated $100,000 \mathrm{~m}^{3}$ of litter from beaches in Brittany, France, costs between 10 and 150 US $\$$ per $\mathrm{m}^{3}$ (Charlier et al. 2008). ${ }^{[1]}$

Natural beach litter, also referred to as beach wrack, mostly consists of seaweed and sea grass in different stages of decay. Such beach wrack plays a key role in Baltic Sea shoreline ecosystems, providing important resources to organisms (Malm et al. 2004) and stabilizing soft bottom substrates. Frequent removal of such beach wrack by grooming reduces species richness and ecological diversity of sandy coasts and increases the risk of beach erosion (Defeo et al. 2009, Gilburn 2012, Malm et al. 2004, Vanhooren et al. 2011). There are, thus, good arguments for removing beach wrack less frequently.

However, accumulations of drifting macrophytes increasingly cause problems in beach environments worldwide and there is often compelling evidence for a direct connection between this increase and anthropogenic nutrient supply (Schramm and Nienhuis 1996, Smetacek and Zingone 2013, Valiela et al. 1997). Seaweed communities typically respond to eutrophication with shifts toward more nutrient-opportunistic components (Troell et al. 2005), which may result in an increased nuisance potential of beach wrack. Significant changes of macroalgal communities after eutrophication have also been observed and documented at the $402 \mathrm{~km}$ long Baltic Sea coast of Schleswig-Holstein (Schramm and Nienhuis 1996, Voigt and Schramm 1991, Weinberger et al. 2020), where 34.8 million of overnight stays and 58.5 million of day visitors generated revenues of 4200 million $€$ in 2019, providing 83,130 persons with a primary income (OstseeHolstein-Tourismus e.V. 2020).

Since beach wrack removal is relatively costly and has a significant negative effect on shoreline ecosystems, information on the nuisance potential of beach wrack (and the necessity of its removal) is relevant for sustainable beach management. The aim of this paper is to provide such information, building on three different approaches. First, we investigate if beach wrack in the area underwent significant compositional change toward more ephemeral and nutrient-opportunistic components. Historical records of beach wrack in the Baltic Sea area are very scarce. A first quantitative study was conducted in August 1977 (Grave and Moeller 1982). It was based upon aerial black-and-white photography and detected $900 \mathrm{~kg}$ of dry biomass per $\mathrm{km}$ of Schleswig-Holstein's Baltic Sea beaches. A repetition of this study in 2012, using exactly the same approach, found $2833 \mathrm{~kg} \mathrm{~km}^{-1}$, corresponding to an increase by a factor of 3.15 (Weinberger et al. 2020). An increase in this order of magnitude alone is unlikely

${ }^{1}$ GEOMAR Helmholtz Centre for Ocean Research, Marine Ecology Division, Kiel, Germany, ${ }^{2}$ Kiel University, Department of Economics, Kiel, Germany, ${ }^{3}$ Kiel Institute for the World Economy, Kiel, Germany, ${ }^{4}$ State Agency for Agriculture, Environment and Rural Areas Schleswig-Holstein, Flintbek, Germany 
Table 1. Geographic coordinates and sampling dates of sites sampled for the quantification and characterization of beach wrack.

\begin{tabular}{llll}
\hline \hline Nr. & Site & Geographic coordinates & Sampling dates \\
\hline 1 & Glücksburg & $54^{\circ} 50^{\prime} 20.58^{\prime \prime} \mathrm{N}, 9^{\circ} 31^{\prime} 06.53^{\prime \prime} \mathrm{E}$ & $15.8 .12 ; 18.8 .13$ \\
2 & Neukirchen & $54^{\circ} 48^{\prime} 11.91^{\prime \prime} \mathrm{N}, 9^{\circ} 44^{\prime} 49.18 \mathrm{E}$ & $15.8 .12 ; 18.8 .13$ \\
3 & Wackerballig & $54^{\circ} 45^{\prime} 30.59^{\prime \prime} \mathrm{N}, 9^{\circ} 52^{\prime} 43.83^{\prime \prime} \mathrm{E}$ & $15.8 .12 ; 18.8 .13$ \\
4 & Schönhagen & $54^{\circ} 37^{\prime} 51.46^{\prime \prime} \mathrm{N}, 10^{\circ} 01^{\prime} 57.50^{\prime \prime} \mathrm{E}$ & $15.8 .12 ; 21.8 .13$ \\
5 & Kiekut & $54^{\circ} 26^{\prime} 53.22^{\prime \prime} \mathrm{N}, 9^{\circ} 52^{\prime} 20.19^{\prime \prime} \mathrm{E}$ & $15.8 .12 ; 21.8 .13$ \\
6 & Strande & $54^{\circ} 26^{\prime} 48.52^{\prime \prime} \mathrm{N}, 10^{\circ} 11^{\prime} 01.80^{\prime \prime} \mathrm{E}$ & $15.8 .12 ; 17.8 .13$ \\
7 & Mönkeberg & $54^{\circ} 21^{\prime} 09.54^{\prime \prime} \mathrm{N}, 10^{\circ} 10^{\prime} 40.06^{\prime \prime} \mathrm{E}$ & $11.8 .12,14.8 .13$ \\
8 & Stein & $54^{\circ} 25^{\prime} 03.76^{\prime \prime} \mathrm{N}, 10^{\circ} 15^{\prime} 55.42^{\prime \prime} \mathrm{E}$ & $16.8 .12 ; 24.9 .13$ \\
9 & Brasilien & $54^{\circ} 25^{\prime} 23.36^{\prime \prime} \mathrm{N}, 10^{\circ} 23^{\prime} 49.71^{\prime \prime} \mathrm{E}$ & $11.8 .12 ; 14.8 .13$ \\
10 & Hohwacht & $54^{\circ} 19^{\prime} 01.73^{\prime \prime} \mathrm{N}, 10^{\circ} 40^{\prime} 42.45^{\prime \prime} \mathrm{E}$ & $16.8 .12 ; 29.8 .13$ \\
11 & Grüner Brink & $54^{\circ} 30^{\prime} 29.94^{\prime \prime} \mathrm{N}, 11^{\circ} 12^{\prime} 04.22^{\prime \prime} \mathrm{E}$ & $14.8 .12 ; 19.8 .13$ \\
12 & Kellenhusen & $54^{\circ} 11^{\prime} 31.44^{\prime \prime} \mathrm{N}, 11^{\circ} 04^{\prime} 07.98^{\prime \prime} \mathrm{E}$ & $14.8 .12 ; 29.8 .13$ \\
13 & Brodtener Ufer & $53^{\circ} 59^{\prime} 32.52^{\prime \prime} \mathrm{N}, 10^{\circ} 50^{\prime} 45.48^{\prime \prime} \mathrm{E}$ & $14.8 .12 ; 29.8 .13$ \\
\hline
\end{tabular}

to explain repeated media coverage and scientific publications (Mossbauer et al. 2012, Weinberger et al. 2020). However, compositional changes of beach wrack probably also occurred in the area, reflecting the documented change in species compositions of macroalgal habitats. We here report the results of an analysis of the recent beach wrack composition on Baltic Sea shores of Schleswig-Holstein and we describe changes since 1977. Second, we extract olfactorial compounds from different types of beach wrack and, monitoring their perception in a public survey, we test the hypothesis that nutrient-opportunistic macrophytes have a higher potential for olfactorial nuisance than those of later successional stages when they are present at similar density. Degrading beached biomass may release intensely odorous volatile compounds, and anoxic decomposition may even result in the production of toxic volatiles, such as hydrogen sulfide $\left(\mathrm{H}_{2} \mathrm{~S}\right)$, at detrimental concentrations (Tauziède et al. 2009). In addition, repeated coverage by the media (Die Welt 2009, Lübecker Nachrichten 2013, Ostsee-Zeitung 2013, 2015, Schleswiger Zeitung 2015, DeutschlandfunkKultur 2018) suggests that the odor emitted by beach wrack constitutes an important component of its nuisance potential toward beach visitors. Third, we report results of an observational field study of beach visitors' behavior in response to different beach wrack which we had distributed at the beach.

\section{METHODS}

\section{Analysis of beach wrack composition}

To determine the quantity and composition of beach wrack along the Baltic Sea coast of the German state Schleswig-Holstein 13 sites were visited in 2012 and 2013 (Table 1). All selected sites were neither subject to beach cleaning, nor protected from waves by artificial infrastructures. Further, they represented the full salinity gradient and were characterized by various types of substratum composition and different main wind exposure directions. All sites were sampled in late summer (all but one in August, Table 1), to allow for a direct comparison with historical data obtained in August 1977 (Grave and Moeller 1982).

For samplings a point in the middle of the drift line marked by presence of beach wrack was selected randomly at each visited site. Two additional points in the drift line were marked in the exact distance of $10 \mathrm{~m}$ to the left and the right of the first point.
At each of the three points, the width of the drift line was measured with a measuring tape. Furthermore, the ground cover of beach wrack within a sampling frame (size: $40 \mathrm{~cm} \mathrm{x} 40 \mathrm{~cm}$ ) was estimated at each point and its thickness was measured at five different positions within the frame. All beach wrack that fell within each frame was collected in plastic bags, transported to the lab, and stored in a freezer. For analysis, all samples were thawed, rinsed with seawater to remove sand, and sorted into phylogenetic groups (Fucus, other Phaeophyta, Zostera, Ulva, other Chlorophyta, Rhodophyta). The sorted material was dried at $70^{\circ} \mathrm{C}$ to weight constancy and weighed. The biomass density per $\mathrm{m}$ of coastline at the sampling sites was calculated by multiplication of biomass present within the frame, 2.5 to extrapolate from the frame size of $0.4 \mathrm{~m}$ to $1 \mathrm{~m}$, and the drift line width. To calculate mean densities and compositions of beach wrack at the sampling sites, data obtained at the three sampling points were averaged.

We compared wind intensities and directions in our sampling area in 2012 and 2013 - as well as in the reference period 1977, as wind must be expected to drive wave action and thereby the accumulation of marine biomass on beaches (Fig. S1). Within the two months during and preceding the sampling periods $\left(1^{\text {st }}\right.$ of July and $31^{\text {st }}$ of August) the main wind directions were W and SE in 2012, and W and ENE in 2013 (Fig. S1a). During the same two months in 1977 less wind from W and considerably more wind from N, NE and E was recorded (Fig. S1a). The average wind speed was $6.0 \mathrm{~m} \mathrm{~s}^{-1}$ in 1977, but only $5.4 \mathrm{~m} \mathrm{~s}^{-1}$ in 2012 and $5.5 \mathrm{~m}$ $\mathrm{s}^{-1}$ in 2013. In particular, wind coming from SW, SE and $\mathrm{N}$ to $\mathrm{E}$ had higher average speeds in the reference period 1977 than in 2012 and 2013 (Fig. S1b). As a consequence, more air coming from sea ( $\mathrm{N}$ to $\mathrm{E}$ ) and less air coming from land (WNW to WSW) crossed the area in 1977 than in the latter two years (Fig. S1c, compare Fig. 2). This probably resulted in more wave impact on surveyed beaches during and immediately prior to the sampling period in 1977 than in 2012/2013.

\section{Sampling of odorants from beach wrack}

Six different macrophytes that are relatively frequent components of macroalgal blooms and beach wrack at the 13 sites were selected for extraction of odorous compounds. They represent the three main phylogenetic groups of marine macrophytes, namely Phaeophyta (Fucus vesiculosus and Dictyosiphon 
foeniculaceus), Chlorophyta (Zostera marina and Ulva compressa) and Rhodophyta (Agarophyton vermiculophyllum and Ceramium tenuicorne). These three groups are known to differ fundamentally in their biochemical composition (van den Hoek et al. 1995) and thereby potentially in their smell nuisance potential. Within each pair of species belonging to the same phylogenetic group, the second ones (D. foeniculaceus, U. compressa and C. tenuicorne) are relatively ephemeral, and short-lived. In contrast, the first ones ( $F$. vesiculosus, $Z$. marina and $A$. vermiculophyllum) all have perennial life strategies. Of them, $Z$. marina and $F$. vesiculosus are the main components of late successional macrophyte communities in the study area (see introduction), while $A$. vermiculophyllum was relatively recently introduced (Weinberger et al. 2008).

Of each species visibly healthy and fresh material, free of other species and of epiphytized specimens, was collected, transported to the lab, and dried in a salad spinner. To obtain comparable degradation conditions portions of $400 \mathrm{~g}$ were placed into separate sealed ziplock bags and incubated together for $7 \mathrm{~d}$ at $22.6^{\circ} \mathrm{C}$ (variability: $20.9-25.9^{\circ} \mathrm{C}$ ) in darkness. After this incubation, all macrophytes were dead and partially degraded. For extraction of odorants they were placed on gauze (mesh size: $1 \mathrm{~mm}$ ) into a funnel and doused with $200 \mathrm{ml}$ of 1,2-propandiol (BASF, Ludwigshafen/Germany). Solvent dripping from the biomass was collected for $4 \mathrm{~min}$, loaded into Sniffin'Sticks (Burghart Messtechnik, Wedel/Germany) (Hummel et al. 1997) and stored at $-20^{\circ} \mathrm{C}$. For control purposes, additional Sniffin'Sticks were loaded with $50 \%$ butanol (Carl Roth, Karlsruhe/Germany) in water (Denzer et al. 2014).

\section{Assessment of public perception of beach wrack odors}

To test our hypothesis that nutrient-opportunistic macrophytes have a higher nuisance potential than those of later successional stages we designed a public survey. The survey consisted of two parts. In the first part, respondents were asked face-to-face about their perception of four different Sniffin'Sticks. Fig. 1 illustrates the test sequence with the four Sniffin'Sticks. All participants started by sniffing the same control stick and were asked to rate its intensity and pleasantness. We used a six-item scale for intensity $(1=$ no smell to $6=$ very strong odor $)$ and a seven-item scale for pleasantness $(-3=$ very unpleasant to $+3=$ very pleasant $)$. Subsequently, participants were presented a Sniffin'Stick with odor extracted from brown, green or red seaweed and asked to rate its intensity and pleasantness. After using the control stick again to neutralize any odor, they were presented another Sniffin'Stick with odor extracted from a seaweed of the same phylogenetic group as the first but with an opponent life strategy and again asked to rate intensity and pleasantness. Except for the control stick, participants never received the same Sniffin'Stick twice. Fifty percent of the participants first received odor from an opportunist and vice versa for the remaining $50 \%$. We distributed the different sequences of the sticks equally across genders. In the second part of the survey, respondents received a clipboard and had to fill out the remaining questions of the survey on their own. This second part of the survey included questions on socio-demographic characteristics.

We conducted the survey in summer 2016 in three places at the German Baltic Sea coast (Kiel, Eckernförde and Schönberg). In Kiel, we approached visitors at a major public festival ("Kiel
Week") and asked them to participate. In Eckernförde and Schönberg, two popular seaside resorts, we asked beach visitors. Table S4 in the appendix provides descriptive statistics of our sample of respondents. Since we found no significant difference between the subsamples in terms of socio-demographic characteristics, we analyzed the three samples jointly. In order to control for differences in the respondents' overall ability to perceive odor, we normalized the odor intensity ratings. To do this, the rating of the control stick was subtracted from the ratings of the sticks with beach wrack extracts. The resulting normalized intensity ratings - as well as the pleasantness ratings - were tested for absence of statistically significant differences using repeated measures-2-way-ANOVA on ranks. As each participant rated odors of one nutrient-opportunistic and one non-opportunistic beach wrack species that both belonged to the same phylogenetic group, the group (green plants, brown algae or red algae) was used as between-subjects factor, while the life strategy (nutrientopportunistic or non-opportunistic) was used as within-subjects factor.

Fig. 1. Test sequence of odor experiment. Participants (= P.) where randomly assigned to one of three treatments (here illustrated by different line contouring).

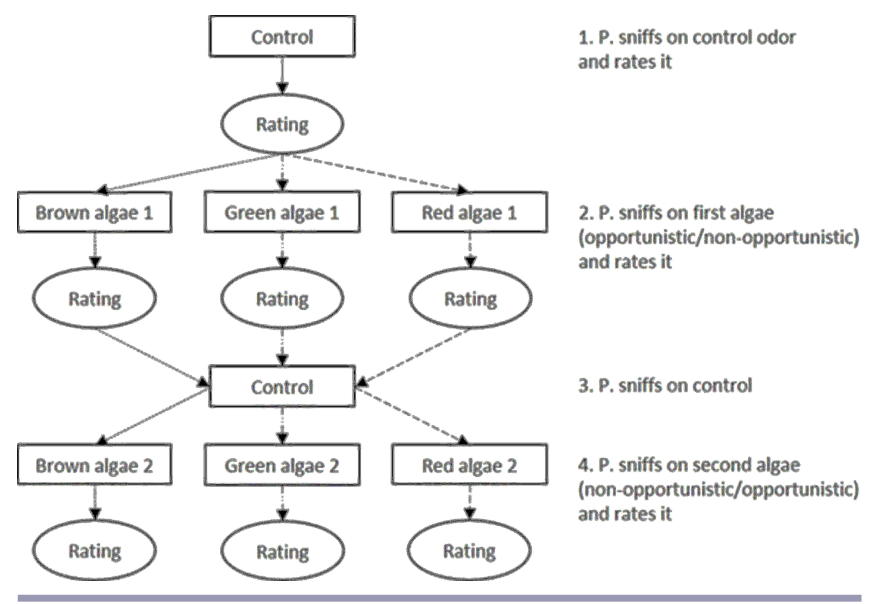

Behavioral responses to beach wrack odor

To verify the different nuisance potentials of selected macrophytes, two experiments were conducted at a seaside resort, Eckernförde, that were based upon the manipulation of beach wrack and the subsequent hidden observation of the behavior of beach visitors. Located at the inner parts of a bay, Eckernförde has $4 \mathrm{~km}$ of sand beach that are a major source of income to this town of 22000 inhabitants.

In experiment 1 , two neighboring beach sections of (A) $106 \mathrm{~m}$ and (B) $30 \mathrm{~m}$ length that extended along the coastline southward and northward of the point $54^{\circ} 27.829^{\prime} \mathrm{N} 9^{\circ} 50.516^{\prime} \mathrm{E}$ were designated as experimental plots. On 17 August 2016, natural beach wrack already present on the site - consisting almost exclusively of eelgrass - was equally distributed with rakes along the drift line of both plots. This resulted in a $20-30 \mathrm{~cm}$ broad line of loose lying beach wrack with a mean fresh weight density of $333 \mathrm{~g}$ per $\mathrm{m}$. In addition, plot $\mathrm{B}$ received $200 \mathrm{~g}$ per $\mathrm{m}$ of partially degraded Ceramium tenuicorne (for the resulting aspect see Fig. 
S1). This material originated from a macroalgal bloom at $54^{\circ}$ $25.397^{\prime} \mathrm{N} 10^{\circ} 23.832^{\prime} \mathrm{E}$. It had been collected on 8 August 2016 with dip nets and stored for $9 \mathrm{~d}$ without water in light-tight plastic bags at ambient temperature $\left(16^{\circ} \mathrm{C}\right.$, range $10^{\circ} \mathrm{C}$ to $\left.20^{\circ} \mathrm{C}\right)$. The preparation of both plots was terminated at 11 am and the behavior of beach visitors was recorded from noon to $5 \mathrm{pm}$. The total number of persons present either on the beach or in the water was counted on each plot in time intervals of $30 \mathrm{~min}$. In addition, the number of people stepping over the beach wrack, mostly swimmers leaving or entering the water, was also counted, as well as the number of persons staying for more than $30 \mathrm{~s}$ in a distance of less than $1 \mathrm{~m}$ of the beach wrack. Observations made within the same time interval on both plots were treated as connected samples and differences in these observations were tested for statistical significance using the t-test or alternatively the Wilcoxon signed ranks test if the assumption of data normal distribution was not fulfilled.

Natural beaching of drifting macrophytes was not observed during experiment 1 , because the Baltic Sea is atidal and wind conditions were extremely calm (bf 1-2, coming from variable directions). In contrast, experiment 2, conducted on 18 and 19 August 2016, was realized with onshore wind on the first day (bf 2 to 5). This caused a steady accumulation of beach wrack (still nearly exclusively eelgrass, see Fig. S3 in appendix) on the shore, except for some sections that were protected by groynes. For this experiment, six new beach sections ( $33 \mathrm{~m}$ to $130 \mathrm{~m}$ long) were designated as experimental plots between the positions $54^{\circ}$ $28.038^{\prime} \mathrm{N} 9^{\circ} 50.446^{\prime} \mathrm{E}$ and $54^{\circ} 27.599^{\prime} \mathrm{N} 9^{\circ} 50.670^{\prime} \mathrm{E}$. Two of these were mechanically cleaned on the morning of day 2 and remained free of beach wrack the entire day. On day 1 between 11:30 am and 4:30 pm and on day 2 between 10:30 am and 3:30 pm the behavior of beach visitors was recorded in intervals of $30 \mathrm{~min}$ as described above for experiment 1 . In addition, the biomass present in all six plots was repeatedly recorded in intervals of approximately $2 \mathrm{~h}$ on both days. To do this the length and breadth of beach wrack present on the plot was measured and all biomass present on three randomly selected beach sections of $50 \mathrm{~cm}$ was collected, weighed with a spring scale and put back. The minimum and maximum biomass densities that were observed on single plots were $0 \mathrm{~g}$ per $\mathrm{m}$ and $15.6 \mathrm{~kg}$ per $\mathrm{m}$ (Fig. S3 in appendix). Their change in 30 min time intervals was estimated based upon differences between subsequent measurements. Best fitting linear functions were adapted to data distributions, using the Prism6 software (Graphpad, Golden/Co.). The t-test or in case of nonnormal data distribution the U-test was used to compare behavior of beach users in absence of beach wrack and in presence of high concentrations of beach wrack.

\section{RESULTS}

\section{Beach wrack composition}

The sampling conducted on Schleswig-Holstein's Baltic Sea coast in late summer 2012 and late summer 2013 indicates that the composition of beach wrack is geographically highly diverse (Fig. 2, for the detailed data set see Tables S1 to S3 in appendix). However, similar species compositions were often found in both years within the same site. Sea grass and bladder wrack dominated beaches in the Northwestern coastal sections of the study area in both years, while various algal opportunists dominated in the Southeastern part of the coast. Filamentous red algae (primarily of the genus Ceramium, sometimes together with Vertebrata fucoides) and filamentous green algae (primarily of the genus Cladophora) contributed the overwhelming quantity of beach wrack in the South East, while the green algal genus Ulva (represented by Ulva compressa) dominated only one site located in the Kiel Fjord (Mönkeberg). Brown filamentous algae of the genera Pylaiella or Ectocarpus were the dominant beach wrack component at the most southern site (Brodtener Ufer) in 2012, but not in 2013. Additional components representing a wide spectrum of red seaweeds (genera Agarophyton, Delesseria, Coccotylus, Ahnfeltia, Furcellaria), brown seaweeds (Chorda, Dictyosiphon) and green seaweeds (Chaetomorpha) were occasionally detected at various sites, but not particularly abundant. The mean quantity of dried beach wrack along the coastline at the 13 visited sites was estimated to be approximately $4.0 \mathrm{~kg} \mathrm{~m}^{-1}$ in 2012 (Table $\mathrm{S} 1$ in appendix) and $2.4 \mathrm{~kg} \mathrm{~m}^{-1}$ in 2013 (Table S2 in appendix), the average of both years was $3.2 \mathrm{~kg} \mathrm{~m}^{-1}$ (Table S3 in appendix). Compared to 1977 (Grave and Möller 1982) the mean relative contribution of Fucus to beach wrack was significantly reduced in 2012 and 2013 (Fig. 3).

Fig. 2. Quantity and composition of beach wrack at 13 sites along the Baltic Sea shore of Schleswig-Holstein in the two periods 12.8. to 16.8.2012 (top) and 14.8. to 24.8.2013

(bottom). Blue numbers correspond with site numbers given in Table 1. No beach wrack was detected in 2013 in site 4 (Schönhagen, see also tables S2A and S2B).

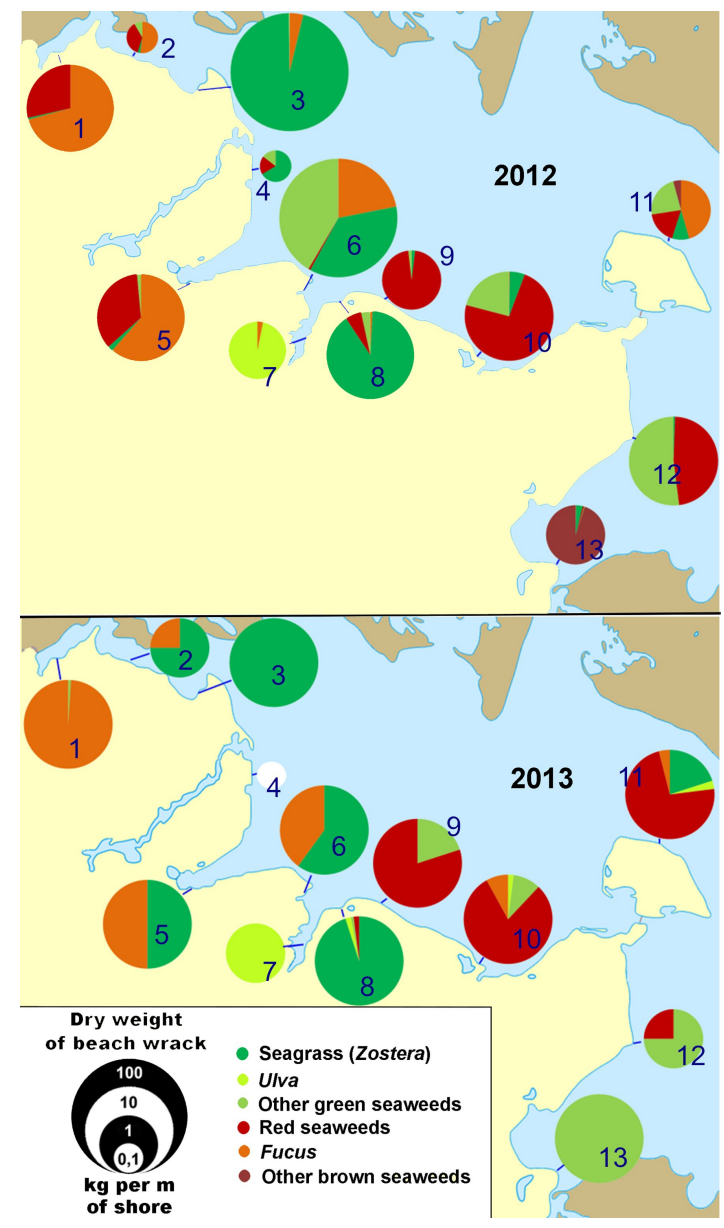


Fig. 3. Contributions of eelgrass, Fucus, and other algal macrophytes to beach wrack at the Baltic Sea shore of Schleswig-Holstein in 1977 (Grave and Moeller 1982) and in the present study. Sizes of pie charts are relative to the absolute quantities of beach wrack in different years.

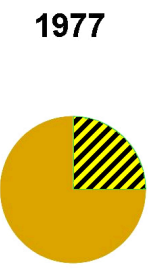

Fucus

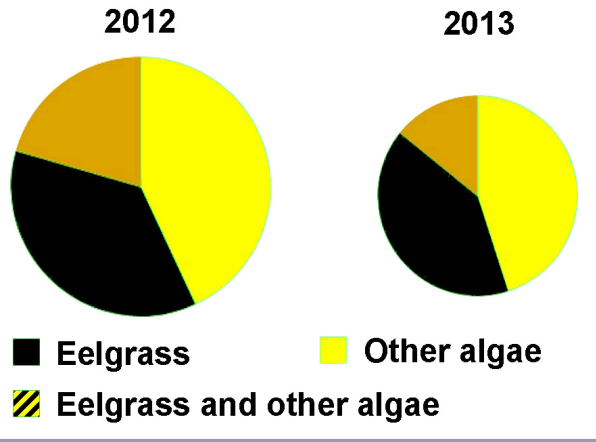

Perception of beach wrack odor nuisance potential

Survey respondents (Fig. 4A, Table S5) perceived the odor intensity of surface extracts generated from equal amounts of degrading macrophytes differently. They rated the odors of all three nutrient-opportunistic seaweeds as significantly more intense than odors of the corresponding non-opportunistic seaweeds of the same phylogenetic group. The mean rank difference between opportunists and non-opportunists was 1.03 on a scale ranging from 0 to 3 . The odors of the opportunistic species Ceramium tenuicorne and Dictyosiphon foeniculaceus were rated as particularly intense, while extracts of the two nonopportunists Fucus vesiculosus and Zostera marina were rated as the least intense odors. The maximal rank difference (Ceramium vs. Zostera) was 1.66. The intensity also differed significantly between all three phylogenetic groups. The smell of red seaweeds was rated as the most intense and odors emitted by green macrophytes as the least intense. In addition, the pleasantness of odors emitted by opportunistic and non-opportunistic degrading macrophytes was perceived differently: the opportunists' smell was perceived as significantly less pleasant (Fig. 4B, Table S6). Moreover, the two red seaweeds, Ceramium tenuicorne and Agarophyton vermiculophyllum, emitted more deterrent odors than the two brown seaweeds or the two green macrophytes. On average, odor emitted by the two late successional species Fucus vesiculosus and Zostera marina was rated as neutral (close to zero), but the smell of the opportunistic $C$. tenuicorne clearly as unpleasant (close to -1).

\section{Experimental verification of nuisance potential}

Avoidance of a whole beach section treated with $C$. tenuicorne at a density of $200 \mathrm{~g} \mathrm{~m}^{-1}$ in addition to eelgrass at $333 \mathrm{~g} \mathrm{~m}^{-1}$ was not observed and the contaminated section was even visited by significantly more persons than the neighboring uncontaminated section, which only harbored $333 \mathrm{~g} \mathrm{~m}^{-1}$ of eelgrass (paired t-test: $p=0.0122$; see Fig. 5A). Moreover, the willingness of beach visitors to step over the beach wrack was not significantly reduced when Ceramium was present (Wilcoxon matched pairs signed ranks test: $\mathrm{p}=0.8457$; Fig. $5 \mathrm{~B})$. However, three beach visitors in the section with Ceramium contamination were overheard complaining to each other about the smell of the beach wrack and the readiness of persons to stay in the close vicinity of this beach wrack was significantly reduced (paired t-test: $\mathrm{p}=0.0276$; Fig. 5C).

Fig. 4. Perception of (A) intensity and (B) pleasantness of odor from six decaying macrophytes. Boxes with whiskers indicate medians and quartiles, while dots indicate arithmetic means. Asterisks, different capitals and different letters indicate treatments that were statistically different in a repeatedmeasures-2-way-ANOVA ( $p<0.05$ in (A) and $\mathrm{p}<0.01$ in (B), see also Tables S5 and S6).
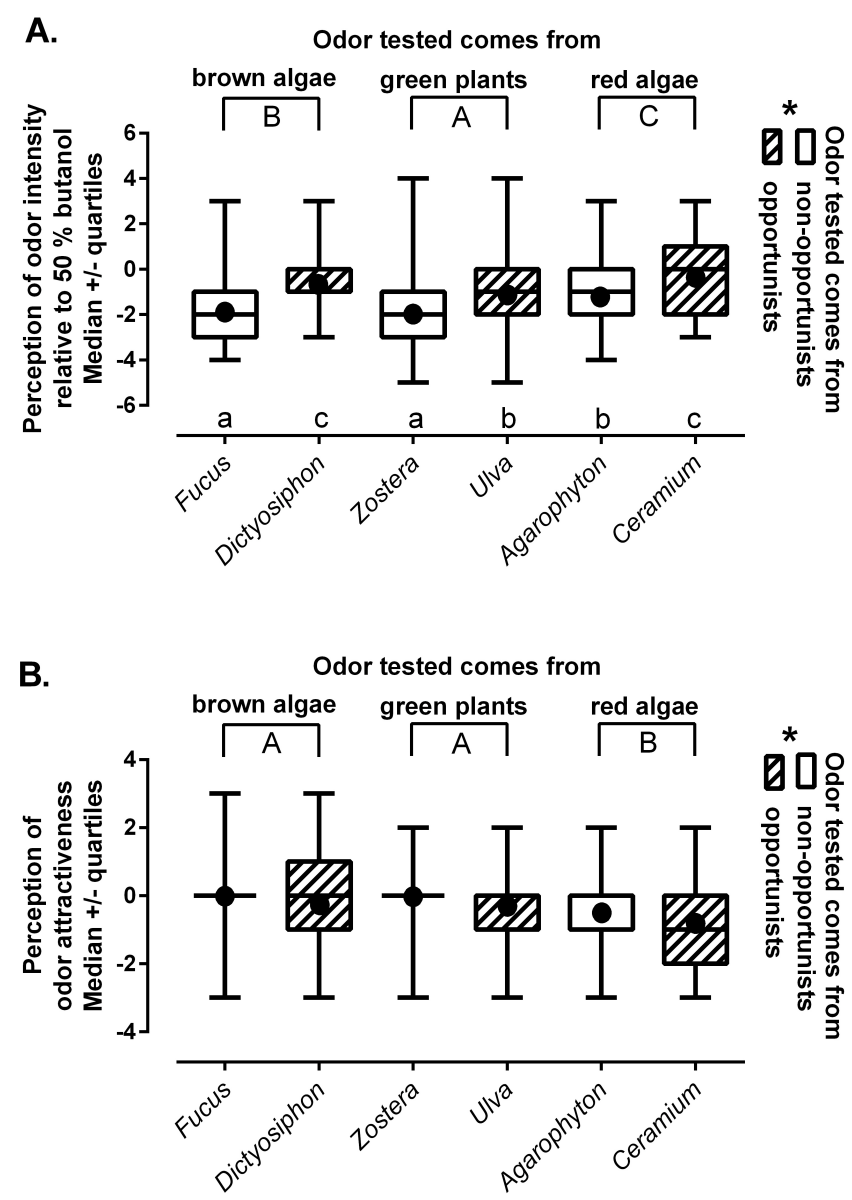

In contrast, presence of eelgrass alone had relatively little influence on the behavior of beach visitors (Fig. S4 in appendix). Their readiness to cross this beach wrack even at the highest densities of 2.2 to $15.6 \mathrm{~kg} \mathrm{~m}^{-1}$ was not lower than their readiness to cross a drift line without any biomass (Mann-Whitney test: $p$ $=0.6009$, Fig. 6A, see also Fig. S3 in appendix). Only the readiness to stay in the close vicinity of beached eelgrass at such high densities decreased significantly (t-test: $p=0.0071$, Fig. 6B), suggesting that $C$. tenuicorne beach wrack raised avoidance behavior in beach users at a lower concentration than $Z$. marina beach wrack. 
Fig. 5. Effect of $0.3 \mathrm{~kg} \mathrm{~m}-1$ of Zostera beach wrack with and without addition of $0.2 \mathrm{~kg} \mathrm{~m}-1$ of Ceramium beach wrack on (A.) the density of visitors at two adjacent beach sections within time intervals of $30 \mathrm{~min}$, (B.) the frequency of these visitors crossing the beach wrack and (C.) the frequency of these visitors staying in direct vicinity of the beach wrack for 30 $\mathrm{s}$ or more time. Repeated measurements were conducted in time intervals of $30 \mathrm{~min}$ between noon and $5 \mathrm{pm}$ and treated as replicates $(n=10)$. Average \pm SD is shown in (A.) and (C.), while median \pm quartiles is shown in (B.). Asterisks indicate pairs of groups that are significantly different $(\mathrm{p}<0.05$; tested with paired t-test in (A.) and (C.) and with Wilcoxon matched pairs signed rank test in (B.).
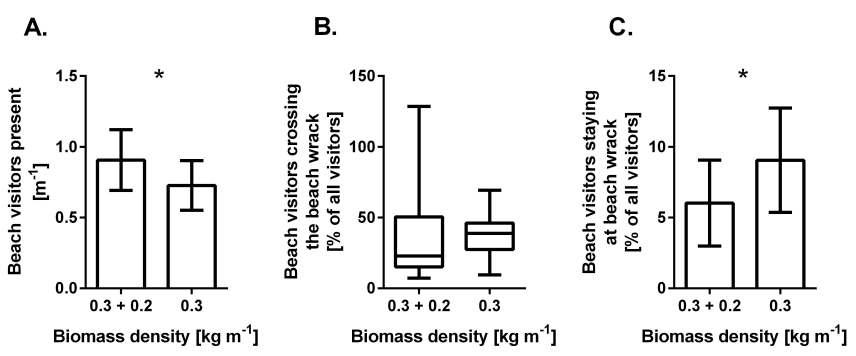

\section{DISCUSSION}

Beach wrack producing macrophytes have been abundant habitat formers in Baltic Sea environments even before the onset of industrialization. Eelgrass (Zostera marina) typically formed extended meadows in close vicinity to the shore (Lehmann 1814) and one eelgrass shoot litters 6 to 30 leaves per year (Mateo et al. 2007). Correspondingly, large accumulations of eelgrass litter have already been observed 200 years ago in the region (Lehmann 1814). Another important component of beach litter in Baltic Sea environments is bladder wrack (Fucus vesiculosus), which is buoyant and drifts after detachment over long distances before it finally accumulates onshore (Rothäusler et al. 2015). In 1977 F. vesiculosus contributed $75 \%$ of the beach wrack on SchleswigHolstein's Baltic Sea coast (Grave and Möller 1982).

Increasing amounts of drifting seaweeds are typically observed in coastal regions that are subject to particularly severe eutrophication, such as Brittany (Charlier et al. 2008) or northern central China (Zhou et al. 2015). Furthermore, in many cases the long-term temporal dynamics of macroalgal blooms reflect increases (Schramm and Nienhuis 1996) and decreases (Beusekom et al. 2009) in eutrophication. However, not all marine macrophytes benefit equally from nutrient supply. Ephemeral nutrient-opportunistic species that are capable of rapid nutrient uptake and rapid growth, but largely devoid of stored nutrient resources are typically limited by external nutrient supply. In contrast, slow-growing and long-living perennial macrophytes, such as Zostera or Fucus, that form the late successional stages of macrophyte habitats benefit much less from eutrophication (Bokn et al. 2003, Pedersen and Borum 1997, Pedersen et al. 2010).
Fig. 6. Effect of Zostera beach wrack absence compared to presence at densities between 2.2 and $15.6 \mathrm{~kg} \mathrm{~m}-1$ on (A.) the frequency of beach visitors crossing the beach wrack and (B.) the frequency of these visitors staying in direct vicinity of the beach wrack for $30 \mathrm{~s}$ or more time. Alltogether 118 repeated measurements were conducted in time intervals of $30 \mathrm{~min}$ on six different beach sections and biomass densities were determined in parallel (see Fig. S1 for the complete data set). Data shown here represent measurements in absence of beach wrack $(n=22)$ and measurements with presence of beach wrack at the highest densities $(n=22)$. Median \pm quartiles is shown in (A.), while average $\pm \mathrm{SD}$ is shown in (B.). Asterisks indicate pairs of groups that are significantly different $(\mathrm{p}<$ 0.05; tested with Mann-Whitney-U-test in (A.) and with Welshcorrected t-test in (B.).
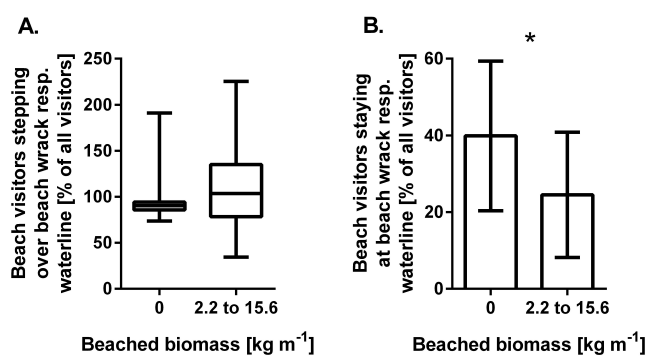

This has also been observed and documented at the Baltic Sea coasts, where massive increases of nitrogen and phosphorous input occurred between 1965 and 1985, followed by only partial reductions (Fleming-Lehtinen et al. 2008, Lennartz et al. 2014). Subsequently, the typical late successional vegetation of shallow water was severely reduced in this area, due to increased competition with fast-growing nutrient opportunists: The standing stock of bladder wrack (Fucus vesiculosus) was reduced by $95 \%$ (Vogt and Schramm 1991) and local decreases were also reported for eelgrass (Zostera marina) (Messner and von Oertzen 1991). At the same time, various nutrient-opportunistic seaweeds became more abundant and the total standing stock of macrophytes rather increased (Schramm and Nienhuis 1996).

The data presented here hint at considerable variability in the distribution of beach wrack along the Baltic Sea coasts of Schleswig-Holstein, which was already detected in 1977 (Grave and Möller 1982). However, the average beach wrack quantity detected in late summer in 2012 and $2013\left(3.2 \mathrm{~kg} \mathrm{~m}^{-1}\right)$ corresponds with an increase by a factor of approximately 3.4 since 1977 $\left(0.9375 \mathrm{~kg} \mathrm{~m}^{-1}\right.$, Grave and Moeller 1982). Our estimate, based upon dry matter determination, is approximately in the same order of magnitude as the estimated increase by a factor of 3.1 that was observed earlier based on aerial photography (Weinberger et al. 2020).

Grave and Möller (1982) provided no information about exact sampling dates and it is for this reason impossible to precisely compare the impact of wind speed and wind direction on quantities of beached biomass in 1977 and 2012/2013. However, altogether a stronger exposure of the studied coastal sections to 
northerly onshore winds was observed in July/August 1977 than in July/August 2012/2013 (Fig. S1) and this difference is reflected in a particularly high beach wrack density in coastal sections exposed toward north in 1977 (Grave and Möller 1982), but not in 2012 and 2013 (Fig. 2). These observations confirm that air exposure in July and August correlates to some degree with beach wrack accumulation in August. The higher detected amounts of biomass in 2012/2013 may then not simply be explained with higher coastal wind exposure during these years, given that this exposure was overall higher in 1977 (Fig. S1), and other causes must have brought about the difference.

Evidence for these causes can be found in the fact that the composition of beach wrack in our study area changed much more than the total amount. (Fig. 3, see also Tabs. S1 to S3 in appendix): In 1977 Fucus contributed on average $75 \%$ of the beach wrack at 10 sites between Flensburg and Neustadt that were investigated (Grave and Möller 1982), while its contribution in 2012 and 2013 was reduced to $21 \%$ and $14 \%$, respectively. As eutrophication has caused a reduction in the depth distribution of Fucus by approximately 50\% since 1976/1978 (Schories et al. 2009; Vogt and Schramm 1991), the standing stock of the species has declined drastically (Schories et al. 2009; Vogt and Schramm 1991), and this is clearly reflected in beach wrack compositions. However, although a similar decline in the standing stock has been observed for eelgrass (Schories et al. 2009) this is not reflected in the quantities that are beached in Schleswig-Holstein. Instead, they rather increased by a factor of at least 4 to 5 (1977: less than $0.23 \mathrm{~kg}$ per m, 2012: $1.45 \mathrm{~kg}$ per m, 2013: $0.96 \mathrm{~kg}$ per m). It currently remains unclear whether this reflects (i) a recovery of the standing stock; (ii) a higher turnover rate (e.g., more production and littering of leaves) than in 1977; or rather (iii) an upward movement of eelgrass within the depth gradient due to increased light limitation (Schramm and Nienhuis 1996), which could bring it into the closer vicinity of beaches. Similar to eelgrass, all other macrophytes except of Fucus also increased. As Grave and Möller (1982) did not distinguish between eelgrass and other algae than Fucus, we have no exact information on the relative contribution of both groups in 1977. In 2012/2013, the group of "other algae" was mainly composed of ephemeral and nutrient-opportunistic red and green filamentous macrophytes of the genera Ceramium, Vertebrata and Cladophora. Each of the two groups (red and green filamentous algae) contributed approximately $20 \%$ to the total amount of beach wrack (Tabs. S1 to $\mathrm{S} 3$ in appendix), which confirms earlier reports of increasing standing stocks of Ceramium tenuicorne in the area (Schramm and Nienhuis 1996). Interestingly, the genus Ulva was much less abundant, although it is by far the most abundant nuisance seaweed on a global scale (Smetacek and Zingone 2013) and ecological impact of Ulva blooms in the region has been observed on a local scale (Steinhagen et al. 2018). Taken together, the total amount of "other algae", consisting primarily of ephemeral species today, increased from less than $0.225 \mathrm{~kg}$ per $\mathrm{m}$ in 1977 (Grave and Moeller 1982) to $1.4 \mathrm{~kg}$ per $\mathrm{m}$ in 2012/2013 (Tab S3 in appendix). This hints at an increase by a factor of at least 6.2. However, given that the value observed in 1977 also, and probably mainly, included eelgrass the true increase of opportunistic seaweeds in the region was probably much more drastic.

To test our hypothesis that nutrient-opportunistic macrophytes have a higher nuisance potential than those of later successional stages when they are present at similar density, we extracted the olfactorial compounds of three nutrient-opportunistic and three non-opportunistic species that had been partially degraded under equal conditions. In a survey, we found that people consistently rated the smell of equal amounts of nutrient-opportunistic species, in particular Ceramium tenuicorne, as more intense and less pleasant than the odor of non-opportunistic species. In particular, odors extracted from the two native perennial species $F$. vesiculosus and $Z$. marina, that have already contributed large amounts of beach wrack in the area prior to the onset of eutrophication (Lehmann 1814), were mostly perceived as smelling rather faint and as neutral in pleasantness. The decomposition rate of beach-cast seaweeds is species-specific (Mews et al. 2007). Nutrient-opportunists in the Baltic Sea are generally characterized by larger surface/volume-ratios than nonopportunists (Wallentinus 1984) and they can for this reason be expected to degrade more rapidly, which may explain their higher potential for olfactorial nuisance.

The particularly high potential of Ceramium litter and the relatively lower potential of eelgrass litter for deterrence was confirmed in field experiments, observing beach visitors' behavior toward beach wrack of known composition and quantity. In these experiments, we measured the combined effect of beach wrack odor and appearance. Eelgrass alone generated a reduced willingness of beach visitors to linger at the water line only when it was present at relatively high concentrations above $2.2 \mathrm{~kg}$ per $\mathrm{m}$. In contrast, only $0.2 \mathrm{~kg}$ per m of Ceramium litter mixed with $0.3 \mathrm{~kg}$ per $\mathrm{m}$ of eelgrass litter was sufficient to cause the same effect. Further, beach visitors were only heard complaining about beach wrack in general and about its odor in particular when Ceramium was present. Based on these observations, and because the odor of Ceramium litter was rated as particularly intense and unpleasant in our survey, we conclude that odor is an important determinant of deterrence by beach wrack, and potentially more important than its appearance.

\section{SPECULATION}

Our comparison of beach wrack composition at German Baltic Sea coasts today with the reference study from 1977 suggests a shift toward more nutrient opportunistic species. Such a change would be expected in principle and appears credible despite the limited availability of historical data, because corresponding changes in the composition of algal habitats in the study area are well documented. At the same time our study of olfactorial perception hints at a higher olfactorial nuisance potential of nutrient opportunistic drift seaweed. Thus, the eutrophication of German Baltic Sea coasts has caused a shift of beach wrack composition toward species with a higher potential for olfactorial deterrence, which could explain recent concerns of local coastal managers despite the limited increase of beached biomass in the study area. A significant reduction of Baltic Sea nutrient levels in the years to come might reverse this trend. However, given that eelgrass litter alone had a deterrent effect when it was present at elevated concentrations its removal from beaches may still be necessary even in a less eutrophicated Baltic Sea environment, despite its importance for the ecosystem. Our study was conducted with selected species from the German Baltic Sea coast. Most other sea areas offer different environmental conditions and harbor different algal species inventories. As a consequence, the specific nuisance potential of SW Baltic Sea beach wrack may 
not be identical to beach wrack in other areas. However, we predict a more or less general validity of our observation that beach wrack composed of nutrient opportunistic algal species has a relatively higher nuisance potential than beach wrack composed of late successional macrophytes.

${ }^{[1]}$ The removed material generally ends up in landfills. To reduce costs for removal opportunities to use the material for energy production, as fertilizer or bio-based compost are discussed (see, e.g., Chubarenko et al. 2021 or Kupczyk et al. 2021).

Responses to this article can be read online at: https://www.ecologyandsociety.org/issues/responses. $\mathrm{php} / 12759$

\section{Acknowledgments:}

The authors are thankful to the cities of Eckernförde and Schönberg for permissions and support with the survey. In particular, Stefan Borgmann (Tourism Management Eckernförde) was extremely supportive, as he also permitted and facilitated the field study. Further, we thank three reviewers for their helpful comments on an earlier version of the paper. This study was supported by the DFG cluster of excellence "Future Ocean" at Kiel (grant number CP1515).

\section{Data Availability:}

The data that support the findings of the olfactorial survey described in this study are available on request from the corresponding author, $F$. W. These data are not publicly available because they contain information that could compromise the privacy of research participants. All other data are included in the paper and its annex. The ethical responsibility of this study - in particular with regard to the handling of personal data - was affirmed by the Central Ethics Committee of Kiel University.

\section{LITERATURE CITED}

Bokn, T., C. M. Duarte, M.F. Pedersen, N. Marbà, F. Moy, C. Barrón, B. Bjerkeng, J. Borum, H. Christie, S. Engelbert, F. L. Fotel, E. E. Hoell, R. Karez, K. Kersting, P. Kraufvelin, C. Lindblad, M. Olsen, K. A. Sanderud, U. Sommer, and K. Sörensen. 2003. The response of experimental rocky shore communities to nutrient addition. Ecosystems 6:577-594. https:// doi.org/10.1007/s10021-002-0108-6

Charlier, R.H., P. Morand, and C.W. Finkl. 2008. How Brittany and Florida coasts cope with green tides. International Journal of Environmental Studies 65:191-208. https://doi. org/10.1080/00207230701791448

Chubarenko B., Woelfel J., Hofmann J., Aldag S., Beldowski J., Burlakovs J., Garrels T., Gorbunova J., Guizani S., Kupczyk A., Kotwicki L., Domnin D., Gajewska M., Hogland W., Kołecka K., Nielsen J., and Schubert H. Converting beach wrack into a resource as a challenge for the Baltic Sea (an overview). 2021
Ocean \& Coastal Management. Vol. 200. 105413. https://doi. org/10.1016/j.ocecoaman.2020.105413

Defeo, O., A. Mclachlan, D.S. Schoeman, T. A. Schlacher, J. Dugan, A. Jones, M. Lastra, and F. Scapini. 2009. Threats to sandy beach ecosystems: A review. Estuarine, Coastal and Shelf Science 81:1-12. https://doi.org/10.1016/j.ecss.2008.09.022

Denzer, M. Y., S. Gailer, D. W. Kern, L.P. Schumm, N. Thuerauf, J. Kornhuber, A. Buettner, and J. Beauchamp. 2014. Quantitative Validation of the n-Butanol Sniffin'Sticks Threshold Pens. Chemosensory Perception 7:91-101. https://doi.org/10.1007/ s12078-014-9168-1

DeutschlandfunkKultur. 2018. Treibsel als natürliche Ressource - Wie Seegras und Algen zu Kissen und Dünger werden. Broadcasted 24.7.2018. https://www.deutschlandfunkkultur.de/ treibsel-als-natuerliche-ressource-wie-seegras-und-algen-zu.976.de. html?dram:article id=423689

Die Welt. 2009. Wege aus der stinkenden Algenplage an der Ostsee. Edition from 20.2.2009. https://www.welt.de/wissenschaft/ article3240109/Wege-aus-der-stinkenden-Algenplage-an-der-Ostsee. html. Accessed 30 June 2019

Fleming-Lehtinen, V., M. Laamanen, H. Kuosa, H. Haahti, and R. Olsonen. 2008. Long-term development of inorganic nutrients and chlorophyll alpha in the open Northern Baltic Sea. Ambio 37:86-92. https://doi.org/10.1579/0044-7447(2008)37[86:1doina] 2.0.co:2

Gilburn, A.S. 2012. Mechanical grooming and beach award status are associated with low strandline biodiversity in Scotland. Estuarine, Coastal and Shelf Science 107:81-88. https://doi. org/10.1016/j.ecss.2012.05.004

Grave, H., and H. Moeller. 1982. Quantification of dead marine plant biomass along the Baltic Sea coast of Western Germany. Helgoländer Meeresuntersuchungen 35:517-519. https://doi. org/10.1007/BF01999139

Haller, I., N. Stybel, S. Schumacher, and M. Mossbauer. 2011. Will Beaches be enough? Future Changes for Coastal Tourism at the German Baltic Sea. Journal of Coastal Research Special Issue: 70-80. https://doi.org/10.2112/SI61-001.68

Hummel, T., B. Sekinger, S.R. Wolf, E. Pauli, and G. Kobal. 1997. 'Sniffin'sticks': olfactory performance assessed by the combined testing of odor identification, odor discrimination and olfactory threshold. Chemical Senses 22:39-52. https://doi.org/10.1093/ chemse/22.1.39

Kupczyk, A., Kołecka K., Gajewska M. 2019. Solving the beach wrack problems by on-site treatment with reed beds towards fertilizer amendments. Journal of Ecological Engineering. Vol. 20(8):252-261. https://doi.org/10.12911/22998993/111717

Lehmann, M.S.S. 1814. Der entdeckte Nutzen des Seegrases zum Füllen der Küssen und Polster. Sehnbothe, Kopenhagen, 28 pp.

Lennartz, S. T., A. Lehmann, J. Herrford, F. Malien, H.P. Hansen, H. Biester, and H.W. Bange. 2014. Long-term trends at the Boknis Eck time series station (Baltic Sea), 1957-2013: does climate change counteract the decline in eutrophication? Biogeosciences 11:6323-6339. https://doi.org/10.5194/bg-11-6323-2014 
Lübecker Nachrichten. 2013. Seegras: Natur pur oder stinkender Unrat? Edition from 5.8.2013. https://www.In-online.de/Lokales/ Nordwestmecklenburg/Seegras-Natur-pur-oder-stinkender-Unrat Accessed 30 June 2019

Malm, T., S. Raberg, S. Fell, and P. Carlsson. 2004. Effects of beach-cast cleaning on beach quality, microbial food web, and littoral macrofaunal biodiversity. Estuarine Coastal and Shelf Science 60: 339-347. https://doi.org/10.1016/j.ecss.2004.01.008

Mateo, M.A., J. Cebriï ${ }^{1} 1 / 2$ n, K. Dunton, and T. Mutchler. 2007. Carbon flux in seagrass ecosystems. In Seagrasses: Biology, Ecology and Conservation. (ed. by A.W.D. Larkum, R.J. Orth, and C. Duarte), pp. 158-192.

Messner, U., and J.A. Von Oertzen. 1991. Long-term changes in the vertical distribution of macrophytobenthic communities in the Greifswalder Bodden. Acta Ichthyologica et Piscatoria 21:135-143. https://doi.org/10.3750/AIP1991.21.S.14

Mews, M., M. Zimmer, and D. E. Jelinski. 2007. Species-specific decomposition rates of beach-cast wrack in Barkley Sound, British Columbia, Canada. Marine Ecology Progress Series 328:155-160. https://doi.org/10.3354/meps328155

Mossbauer, M., I. Haller, S. Dahlke, and G. Schernewski. 2012. Management of stranded eelgrass and macroalgae along the German Baltic coastline. Ocean \& Coastal Management 57:1-9. https://doi.org/10.1016/j.ocecoaman.2011.10.012

Ostsee-Holstein-Tourismus e.V. 2020. Erfolgreiche Ostsee: Erhebliche Zuwächse in den letzten fünf Jahren an der Ostsee Schleswig-Holsteins. https://www.presseportal.de/pm/59512/4731046 Accessed 27 June 2021

Ostsee-Zeitung. 2013. Algen-Plage: Urlauber ekeln sich. Edition from 24.7.2013. https://www.ostsee-zeitung.de/Mecklenburg/ Rostock/Algen-Plage-Urlauber-ekeln-sich. Accessed 30 June 2019

Ostsee-Zeitung. 2015. Stinkende Algen werden zum Problem. Edition from 9.6.2015. https://www.ostsee-zeitung.de/Vorpommern/ Ruegen/Stinkende-Algen-werden-zum-Problem. Accessed 30 June 2019

Pedersen, M.F. and J. Borum. 1997. Nutrient control of estuarine macroalgae: growth strategy and the balance between nitrogen requirements and uptake. Marine Ecology-Progress Series 161:155-163. https://doi.org/10.3354/meps161155

Pendleton, L.H. 2007. The Economic and Market Value of Coasts and Estuaries: What's At Stake? Restore Americas Estuaries, Arlington, VA. 175 pp.

Rothäusler E, H. Corell, and V. Jormalainen. 2015. Abundance and dispersal trajectories of floating Fucus vesiculosus in the Northern Baltic Sea. Limnology and Oceanography 60:2173-2184 https://doi.org/10.1002/lno.10195

Schleswiger Nachrichten. 2015. Stinkendes Seegras an der Ostsee nervt Touristen. Edition from 31.7.2015. https://www.shz. de/10344831. Accessed 30 June 2019

Schories, D., C. Pehlke, and U. Selig. 2009. Depth distributions of Fucus vesiculosus L. and Zostera marina L. as classification parameters for implementing the European Water Framework
Directive on the German Baltic coast. Ecological Indicators 9:670-680. https://doi.org/10.1016/j.ecolind.2008.08.010

Schramm, W., and P.H. Nienhuis. 1996. Marine benthic vegetation. Recent changes and the effects of eutrophication. In: Marine benthic vegetation. Recent changes and the effects of eutrophication. Springer-Verlag, Berlin (Germany), 470 pp. https://doi.org/10.1007/978-3-642-61398-2

Smetacek, V. and A. Zingone. 2013. Green and golden seaweed tides on the rise. Nature 504:84-88. https://doi.org/10.1038/ nature 12860

Steinhagen, S., F. Weinberger, and R. Karez. 2018. Molecular analysis of Ulva compressa (Chlorophyta, Ulvales) reveals its morphological plasticity, distribution and potential invasiveness on German North Sea and Baltic Sea coasts. European Journal of Phycology 54:102-114. https://doi.org/10.1080/09670262.2018.1513167

Tauziède, C., A. Morin, H. Biaudet, A. Hervé, N. Chatellier, C. Villey, Y. Dupuis, and K. Adam. 2009. Résultats des mesures ponctuelles des émissions d'hydrogène sulfuré et autres composés gazeux potentiellement toxiques issues de la fermentation d'algues vertes (ulves). INERIS document nr. DRC-09-108407-10226A, $15 \mathrm{pp}$.

Troell, M., L. Pihl, P. Rönnbäck, H. Wennhage, T. Söderqvist and N. Kautsky. 2005. Regime shifts and ecosystem services in Swedish coastal soft bottom habitats: when resilience is undesirable. Ecology and Society 10(1):30. http://www. ecologyandsociety.org/vol10/iss1/art30/ https://doi.org/10.5751/ ES-01374-100130

Valiela, I., J. Mcclelland, J. Hauxwell, P.J. Behr, D. Hersh and K. Foreman. 1997. Macroalgal blooms in shallow estuaries:Controls and ecophysiological and ecosystem consequences. Limnology and Oceanography 42:1105-1118. https://doi.org/10.4319/ $\underline{\text { lo.1997.42.5 part } 2.1105}$

van Beusekom, J.E.E., P.V.M. Bot, J. Carstensen, J.H.M. Goebel, H. Lenhart, J. Pi $i_{i}^{1 / 2 t s c h}$, T. Petenati, T. Raabe, K. Reise, and B. Wetsteijn. (2009) Eutrophication.Thematic Report No. 6. Common Wadden Sea Secretariat, Trilateral Monitoring and Assessment Group, Wilhelmshaven 22 pp.

van den Hoek C., D. G. Mann, H.M. Jahns. 1995. Algae: An Introduction to Phycology. Cambridge University Press, 623 pp.

Vanhooren, S., H. Maelfait and K. Belpaeme. 2011. Moving Towards an Ecological Management of the Beaches. Journal of Coastal Research SI61:81-86. https://doi.org/10.2112/SI61-001.70

Vaz, B., A. T. Williams, C.P. Da Silva and M. Phillips. 2009. The importance of user's perception for beach management. Journal of Coastal Research: 1164-1168.

Vogt, H., and W. Schramm. 1991. Conspicuous decline of Fucus in Kiel Bay (Western Baltic): what are the causes? Marine Ecology-Progress Series 69:189-194. https://doi.org/10.3354/ $\underline{\text { meps069189 }}$

Wallentinus I. 1984. Comparisons of nutrient uptake rates for Baltic macroalgae with different thallus morphologies Marine Biology 80:215-225. https://doi.org/10.1007/BF02180189 
Weinberger, F., B. Buchholz, R. Karez and M. Wahl. 2008. The invasive red alga Gracilaria vermiculophylla in the Baltic Sea: adaptation to brackish water may compensate for light limitation. Aquatic Biology 3: 251-264. https://doi.org/10.3354/ab00083

Weinberger, F., T. Paalme, and S.A. Wikström. 2020. Seaweed resources of the Baltic Sea, Kattegatt and German and Danish North Sea coasts. Botanica Marina 63:61-72. https://doi. org/10.1515/bot-2019-0019

Williams, A. T., and A. Barugh. 2014. Beach user perceptions at the eastern Yucatan peninsula, Mexico Journal of Coastal Research 70:426-430. https://doi.org/doi:10.2112/si70-072.1

Zhou, Y. P., L. J. Tan, Q. T. Pang, F. Li and J. T. Wang. 2015. Influence of nutrients pollution on the growth and organic matter output of Ulva prolifera in the southern Yellow Sea, China Marine Pollution Bulletin 95:107-114. https://doi.org/10.1016/j. marpolbul.2015.04.034 
Table S1A: Dry matter of different macrophytes in beach wrack sampled in August 2012, related to length of beach line $\left[\mathrm{kg} \mathrm{m}^{-1}\right]$

\begin{tabular}{|c|c|c|c|c|c|c|c|c|}
\hline Site & $\begin{array}{r}\text { A. } \\
\text { Fucus }\end{array}$ & $\begin{array}{r}\text { B. } \\
\text { Zostera }\end{array}$ & C. Ulva & $\begin{array}{l}\text { D. other } \\
\text { Chloro- } \\
\text { phyta }\end{array}$ & $\begin{array}{r}\text { E. Rhodo- } \\
\text { phyta }\end{array}$ & $\begin{array}{r}\text { F. other } \\
\text { Phaeophyta }\end{array}$ & $\begin{array}{r}\text { Opportunists } \\
\text { (sum of C to } \\
\text { F) }\end{array}$ & Total \\
\hline Glücksburg & 2.054 & 0.018 & 0 & 0 & 0.828 & 0 & 0.828 & 2.900 \\
\hline Neukirchen & 0.031 & 0.002 & 0 & 0.005 & 0.022 & 0 & 0.027 & 0.060 \\
\hline Wackerballig & 0.376 & 9.621 & 0 & 0.019 & 0 & 0 & 0.019 & 10.015 \\
\hline Schönhagen & 0 & 0.043 & 0 & 0.009 & 0.012 & 0 & 0.022 & 0.065 \\
\hline Kiekut & 3.833 & 0.118 & 0 & 0.092 & 2.190 & 0 & 2.282 & 6.233 \\
\hline Strande & 4.084 & 6.709 & 0 & 7.743 & 0.103 & 0.006 & 7.852 & 18.645 \\
\hline Mönkeberg & 0.010 & 0 & 0.312 & 0 & 0 & 0 & 0.312 & 0.322 \\
\hline Stein & 0.017 & 1.848 & 0 & 0.070 & 0.122 & 0 & 0.192 & 2.056 \\
\hline Brasilien & 0 & 0.006 & 4.6E-06 & 0.006 & 0.330 & 0 & 0.336 & 0.342 \\
\hline Hohwacht & 0.019 & 0.469 & 0 & 1.789 & 6.283 & 0.003 & 8.075 & 8.563 \\
\hline Grüner Brink & 0.275 & 0.056 & 0 & 0.139 & 0.106 & 0.026 & 0.272 & 0.602 \\
\hline Kellenhusen & 0 & 0.009 & 0 & 0.846 & 0.772 & 0 & 1.619 & 1.628 \\
\hline Brodten & 0.001 & 0.022 & 0 & 0.002 & 0.004 & 0.551 & 0.557 & 0.580 \\
\hline Mean & 0.823 & 1.455 & 0.024 & 0.825 & 0.829 & 0.045 & 1.722 & 4.001 \\
\hline
\end{tabular}

Table S1B: Relative contribution [\%] of different macrophytes to dry weight of beach wrack sampled in August 2012.

\begin{tabular}{|c|c|c|c|c|c|c|c|}
\hline Site & $\begin{array}{r}\text { A. } \\
\text { Fucus }\end{array}$ & $\begin{array}{r}\text { B. } \\
\text { Zostera }\end{array}$ & $\begin{array}{r}\text { C. } \\
\text { Ulva }\end{array}$ & $\begin{array}{l}\text { D. other } \\
\text { Chlorophyta }\end{array}$ & $\begin{array}{r}E . \\
\text { Rhodophyta }\end{array}$ & $\begin{array}{r}\text { F. other } \\
\text { Phaeophyta }\end{array}$ & $\begin{array}{r}\text { Opportunists } \\
\text { (sum of C to } \\
F \text { ) }\end{array}$ \\
\hline Glücksburg & 70.8 & 0.6 & 0.0 & 0.0 & 28.5 & 0.0 & 28.5 \\
\hline Neukirchen & 52.2 & 2.6 & 0.0 & 8.4 & 36.8 & 0.0 & 45.2 \\
\hline Wackerballig & 3.8 & 96.1 & 0.0 & 0.2 & 0.0 & 0.0 & 0.2 \\
\hline Schönhagen & 0.0 & 66.5 & 0.0 & 14.6 & 18.9 & 0.0 & 33.5 \\
\hline Kiekut & 61.5 & 1.9 & 0.0 & 1.5 & 35.1 & 0.0 & 36.6 \\
\hline Strande & 21.9 & 36.0 & 0.0 & 41.5 & 0.6 & 0.0 & 42.1 \\
\hline Mönkeberg & 3.1 & 0.0 & 96.9 & 0.0 & 0.0 & 0.0 & 96.9 \\
\hline Stein & 0.8 & 89.9 & 0.0 & 3.4 & 5.9 & 0.0 & 9.3 \\
\hline Brasilien & 0.0 & 1.9 & 0.0 & 1.8 & 96.3 & 0.0 & 98.1 \\
\hline Hohwacht & 0.2 & 5.5 & 0.0 & 20.9 & 73.4 & 0.0 & 94.3 \\
\hline Grüner Brink & 45.6 & 9.3 & 0.0 & 23.1 & 17.7 & 4.3 & 45.1 \\
\hline Kellenhusen & 0.0 & 0.6 & 0.0 & 52.0 & 47.4 & 0.0 & 99.4 \\
\hline Brodten & 0.2 & 3.7 & 0.0 & 0.3 & 0.7 & 95.0 & 96.1 \\
\hline Mean & 20.6 & 36.4 & 0.6 & 20.6 & 20.7 & 1.1 & 43.1 \\
\hline
\end{tabular}


Table S2A: Dry matter of different macrophytes in beach wrack sampled in August/September 2013, related to length of beach line $\left[\mathrm{kg} \mathrm{m}^{-1}\right]$

\begin{tabular}{|c|c|c|c|c|c|c|c|c|}
\hline Site & $\begin{array}{r}\text { A. } \\
\text { Fucus }\end{array}$ & $\begin{array}{r}\text { B. } \\
\text { Zostera }\end{array}$ & C. Ulva & $\begin{array}{l}\text { D. other } \\
\text { Chloro- } \\
\text { phyta }\end{array}$ & $\begin{array}{r}\text { E. Rhodo- } \\
\text { phyta }\end{array}$ & $\begin{array}{l}\text { F. other } \\
\text { Phaeophyta }\end{array}$ & $\begin{array}{r}\text { Opportunists } \\
\text { (sum of C to } \\
\text { F) }\end{array}$ & Total \\
\hline Glücksburg & 2.327 & 0 & 0 & 0.024 & 0 & 0 & 0.024 & 2.351 \\
\hline Neukirchen & 0.173 & 0.518 & 0 & 0 & 0 & 0 & 0 & 0.691 \\
\hline Wackerballig & 0 & 5.878 & 0 & 0 & 0 & 0 & 0 & 5.878 \\
\hline Schönhagen & 0 & 0 & 0 & 0 & 0 & 0 & 0 & \\
\hline Kiekut & 0.694 & 0.694 & 0 & 0 & 0 & 0 & 0 & 1.387 \\
\hline Strande & 0.819 & 1.228 & 0 & 0 & 0 & 0 & 0 & 2.046 \\
\hline Mönkeberg & 0 & 0 & 0.177 & 0 & 0 & 0 & 0.177 & 0.177 \\
\hline Stein & 0 & 3.295 & 0.069 & 0.035 & 0.069 & $v$ & 0.173 & 3.468 \\
\hline Brasilien & 0 & 0 & 0 & 0.319 & 1.275 & 0 & 1.594 & 1.594 \\
\hline Hohwacht & 0.159 & 0 & 0.040 & 0.198 & 1.587 & 0 & 1.825 & 1.984 \\
\hline Grüner Brink & 0.212 & 1.062 & 0.159 & 0 & 3.876 & 0 & 4.035 & 5.310 \\
\hline Kellenhusen & 0 & 0 & 0 & 0.645 & 0.215 & 0 & 0.860 & 0.860 \\
\hline Brodten & 0 & 0 & 0 & 5.310 & 0 & 0 & 5.310 & 5.310 \\
\hline Mean & 0.337 & 0.975 & 0.034 & 0.502 & 0540 & 0 & 1.077 & $2.38 \mathrm{~s}$ \\
\hline
\end{tabular}

Table S2B: Relative contribution [\%] of different macrophytes to dry weight of beach wrack sampled in August/September 2013.

\begin{tabular}{|c|c|c|c|c|c|c|c|}
\hline Site & $\begin{array}{r}\text { A. } \\
\text { Fucus }\end{array}$ & $\begin{array}{r}\text { B. } \\
\text { Zostera }\end{array}$ & $\begin{array}{r}\text { C. } \\
\text { Ulva }\end{array}$ & $\begin{array}{r}\text { D. other } \\
\text { Chlorophyta }\end{array}$ & $\begin{array}{r}\text { E. } \\
\text { Rhodophyta }\end{array}$ & $\begin{array}{r}\text { F. other } \\
\text { Phaeophyta }\end{array}$ & $\begin{array}{r}\text { Opportunists } \\
\text { (sum of C to } \\
\text { F) }\end{array}$ \\
\hline Glücksburg & 99.0 & 0.0 & 0.0 & 1.0 & 0.0 & 0.0 & 1.0 \\
\hline Neukirchen & 25.0 & 75.0 & 0.0 & 0.0 & 0.0 & 0.0 & 0.0 \\
\hline $\begin{array}{l}\text { Wackerballig } \\
\text { Schönhagen }\end{array}$ & 0.0 & 100.0 & 0.0 & 0.0 & 0.0 & 0.0 & 0.0 \\
\hline Kiekut & 50.0 & 50.0 & 0.0 & 0.0 & 0.0 & 0.0 & 0.0 \\
\hline Strande & 40.0 & 60.0 & 0.0 & 0.0 & 0.0 & 0.0 & 0.0 \\
\hline Mönkeberg & 0.0 & 0.0 & 100.0 & 0.0 & 0.0 & 0.0 & 100.0 \\
\hline Stein & 0.0 & 95.0 & 2.0 & 1.0 & 2.0 & 0.0 & 5.0 \\
\hline Brasilien & 0.0 & 0.0 & 0.0 & 20.0 & 80.0 & 0.0 & 100.0 \\
\hline Hohwacht & 8.0 & 0.0 & 2.0 & 10.0 & 80.0 & 0.0 & 92.0 \\
\hline Grüner Brink & 4.0 & 20.0 & 3.0 & 0.0 & 73.0 & 0.0 & 76.0 \\
\hline Kellenhusen & 0.0 & 0.0 & 0.0 & 75.0 & 25.0 & 0.0 & 100.0 \\
\hline Brodten & 0.0 & 0.0 & 0.0 & 100.0 & 0.0 & 0.0 & 100.0 \\
\hline Mean & 14.1 & 40.8 & 1.4 & 21.0 & 22.6 & 0.0 & 45.1 \\
\hline
\end{tabular}


Table S3A: Mean dry matter of different macrophytes in beach wrack sampled in 2012 and 2013, related to length of beach line $\left[\mathrm{kg} \mathrm{m}^{-1}\right]$

\begin{tabular}{|c|c|c|c|c|c|c|c|c|}
\hline Site & $\begin{array}{r}\text { A. } \\
\text { Fucus }\end{array}$ & $\begin{array}{r}\text { B. } \\
\text { Zostera }\end{array}$ & C. Ulva & $\begin{array}{l}\text { D. other } \\
\text { Chloro- } \\
\text { phyta }\end{array}$ & $\begin{array}{r}\text { E. Rhodo- } \\
\text { phyta }\end{array}$ & $\begin{array}{r}\text { F. other } \\
\text { Phaeophyta }\end{array}$ & $\begin{array}{r}\text { Opportunists } \\
\text { (sum of C to } \\
\text { F) }\end{array}$ & Total \\
\hline Glücksburg & 2.191 & 0.009 & 0 & 0.012 & 0.414 & 0 & 0.426 & 2.625 \\
\hline Neukirchen & 0.102 & 0.260 & 0 & 0.003 & 0.011 & 0 & 0.013 & 0.375 \\
\hline Wackerballig & 0.188 & 7.749 & 0 & 0.010 & 0 & 0 & 0.010 & 7.947 \\
\hline Schönhagen & 0 & 0.021 & 0 & 0.005 & 0.006 & 0 & 0.011 & 0.032 \\
\hline Kiekut & 2.263 & 0.406 & 0 & 0.046 & 1.095 & 0 & 1.141 & 3.810 \\
\hline Strande & 2.451 & 3.969 & 0 & 3.871 & 0.052 & 0.003 & 3.926 & 10.346 \\
\hline Mönkeberg & 0.005 & 0 & 0.244 & 0 & 0 & 0 & 0.244 & 0.249 \\
\hline Stein & 0.008 & 2.571 & 0.035 & 0.052 & 0.096 & 0 & 0.183 & 2.762 \\
\hline Brasilien & 0 & 0.003 & 2.3E-06 & 0.163 & 0.802 & 0 & 0.965 & 0.968 \\
\hline Hohwacht & 0.089 & 0.235 & 0.020 & 0.994 & 3.935 & 0.002 & 4.950 & 5.274 \\
\hline Grüner Brink & 0.243 & 0.559 & 0.080 & 0.070 & 1.991 & 0.013 & 2.153 & 2.956 \\
\hline Kellenhusen & 0 & 0.005 & 0 & 0.746 & 0.494 & 0 & 1.239 & 1.244 \\
\hline Brodten & 0.001 & 0.011 & 0 & 2.656 & 0.002 & 0.276 & 2.933 & 2.945 \\
\hline Mean & 0.580 & 1.215 & 0.029 & 0.663 & 0.684 & 0.023 & 1.400 & 3.195 \\
\hline
\end{tabular}

Table S3B: Average contribution [\%] of different macrophytes to dry weight of beach wrack sampled in 2012 and 2013.

\begin{tabular}{|c|c|c|c|c|c|c|c|}
\hline Site & $\begin{array}{r}\text { A. } \\
\text { Fucus }\end{array}$ & $\begin{array}{r}\text { B. } \\
\text { Zostera }\end{array}$ & $\begin{array}{r}\text { C. } \\
\text { Ulva }\end{array}$ & $\begin{array}{l}\text { D. other } \\
\text { Chlorophyta }\end{array}$ & $\begin{array}{r}\text { E. } \\
\text { Rhodophyta }\end{array}$ & $\begin{array}{r}\text { F. other } \\
\text { Phaeophyta }\end{array}$ & $\begin{array}{r}\text { Opportunists } \\
\text { (sum of C to } \\
\text { F) }\end{array}$ \\
\hline Glücksburg & 83.4 & 0.3 & 0.0 & 0.4 & 15.8 & 0.0 & 16.2 \\
\hline Neukirchen & 27.2 & 69.2 & 0.0 & 0.7 & 2.9 & 0.0 & 3.6 \\
\hline Wackerballig & 2.4 & 97.5 & 0.0 & 0.1 & 0.0 & 0.0 & 0.1 \\
\hline Schönhagen & 0.0 & 66.5 & 0.0 & 14.6 & 18.9 & 0.0 & 33.5 \\
\hline Kiekut & 59.4 & 10.6 & 0.0 & 1.2 & 28.7 & 0.0 & 29.9 \\
\hline Strande & 23.7 & 38.4 & 0.0 & 37.4 & 0.5 & 0.0 & 37.9 \\
\hline Mönkeberg & 2.0 & 0.0 & 98.0 & 0.0 & 0.0 & 0.0 & 98.0 \\
\hline Stein & 0.3 & 93.1 & 1.3 & 1.9 & 3.5 & 0.0 & 6.6 \\
\hline Brasilien & 0.0 & 0.3 & 0.0 & 16.8 & 82.9 & 0.0 & 99.7 \\
\hline Hohwacht & 1.7 & 4.4 & 0.4 & 18.8 & 74.6 & 0.0 & 93.9 \\
\hline Grüner Brink & 8.2 & 18.9 & 2.7 & 2.4 & 67.4 & 0.4 & 72.9 \\
\hline Kellenhusen & 0.0 & 0.4 & 0.0 & 59.9 & 39.7 & 0.0 & 99.6 \\
\hline Brodten & 0.0 & 0.4 & 0.0 & 90.2 & 0.1 & 9.4 & 99.6 \\
\hline Mean & 18.2 & 38.0 & 0.9 & 20.8 & 21.4 & 0.7 & 43.8 \\
\hline
\end{tabular}


Table S4: Distribution of characteristics over samples of respondents in surveys conducted at Kiel, Schönberg, Eckernförde and in total. Absolute numbers are given if not stated otherwise.

\begin{tabular}{|c|c|c|c|c|c|}
\hline Characteristics & Value & Kiel & Schönberg & Eckernförde & Total $^{\mathrm{a}}$ \\
\hline Sample size & & 60 & 61 & 56 & 177 \\
\hline \multirow[t]{2}{*}{ Gender } & Female & 35 & 30 & 34 & $99(55.57 \%)$ \\
\hline & Male & 25 & 31 & 20 & 76 (43.43\%) \\
\hline Age in years & Average & 47.53 & 47.36 & 55.94 & 50.27 \\
\hline Household size & Average & 2.25 & 2.74 & 2.34 & 2.45 \\
\hline $\begin{array}{l}\text { Household net } \\
\text { income }\end{array}$ & Median categoryb & $2500-2599 €$ & $2600-3599 €$ & $2500-2599 €$ & $2500-2599 €$ \\
\hline School & 9 years & 5 & 5 & 6 & $16(9.04 \%)$ \\
\hline \multirow[t]{4}{*}{ education } & 10 years & 12 & 24 & 15 & $51(28.81 \%)$ \\
\hline & $12-13$ years & 15 & 17 & 17 & $49(27.68 \%)$ \\
\hline & $\begin{array}{l}\text { Graduated in } \\
\text { college }\end{array}$ & 17 & 10 & 14 & $41(23.16 \%)$ \\
\hline & Missing information & 11 & 5 & 4 & $20(11.29 \%)$ \\
\hline
\end{tabular}

${ }^{a}$ If numbers do not sum up to total sample size this is due to missing observations.

${ }^{\mathrm{b}}$ A number of participants did not provide information on their household's net income. 
Table S5: Repeated measures-2-way-ANOVA of the normalized and ranked perception of intensity of odor from six decaying macrophytes. Phylogenetic groups (= PG, green plants, brown algae or red algae) were used as between subject factor and life strategy (= LS, opportunistic or non-opportunistic) was used as within subject factor. See also Figure 4A.

Source

Between subject effects

Intercept

PG

Error

Within subject contrasts

LS

PG*LS

Error (LS)

SS

df 2840001

179

187523

2243180

174

MS

F

P 
Table S6: Repeated measures-2-way-ANOVA of the ranked perception of pleasantness of odor from six decaying macrophytes. Phylogenetic groups (= PG, green plants, brown algae or red algae) were used as between subject factor and life strategy (= LS, opportunistic or non-opportunistic) was used as within subject factor. See also Figure 4B.

Source

Between subject effects

Intercept

PG

Error

Within subject contrasts

LS

PG*LS

Error (LS)

SS

Df

$1982892 \quad 179$

130216

2

1777907

174

MS

F

P

P 
Figure S1: Frequency of wind directions (A), average wind speed from different directions $(B)$ and overall air stream from different directions $(C)$, recorded at $54.5272^{\circ} \mathrm{N} 11.0580^{\circ} \mathrm{E}$ (meteorological station Fehmarn) between $1^{\text {st }}$ of July and $31^{\text {st }}$ of August in the years 1977, 2012 and 2013. Wind direction was recorded in hourly intervals and in increments of $10^{\circ}$. Wind speed was recorded in the same hourly intervals. Air stream is the overall length of the air stream coming from a given direction that passed the area within the recording period and was calculated by multiplication of data shown in A and B. Data kindly provided by Deutscher Wetterdienst.

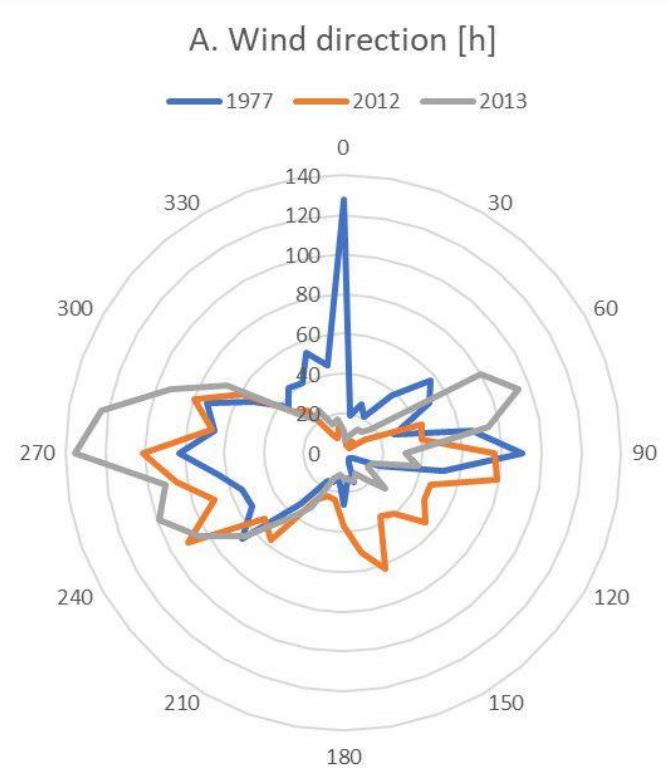

180
B. Wind speed $\left[\mathrm{m} \mathrm{s}^{-1}\right]$

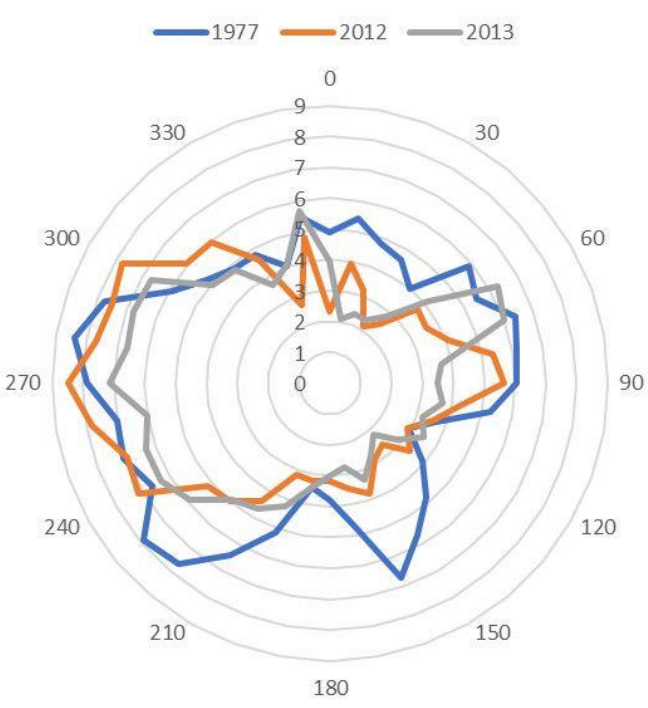

180

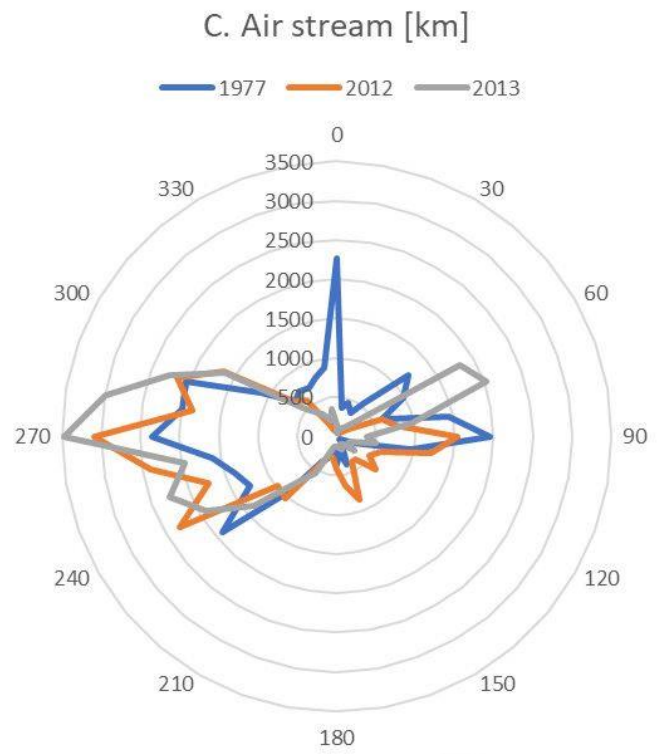


Figure S2: Density of beach wrack (333 $\mathrm{g} \mathrm{m}^{-1}$ eelgrass $+200 \mathrm{~g} \mathrm{~m}^{-1}$ Ceramium) tested for effects on beach visitors in field experiment 1.

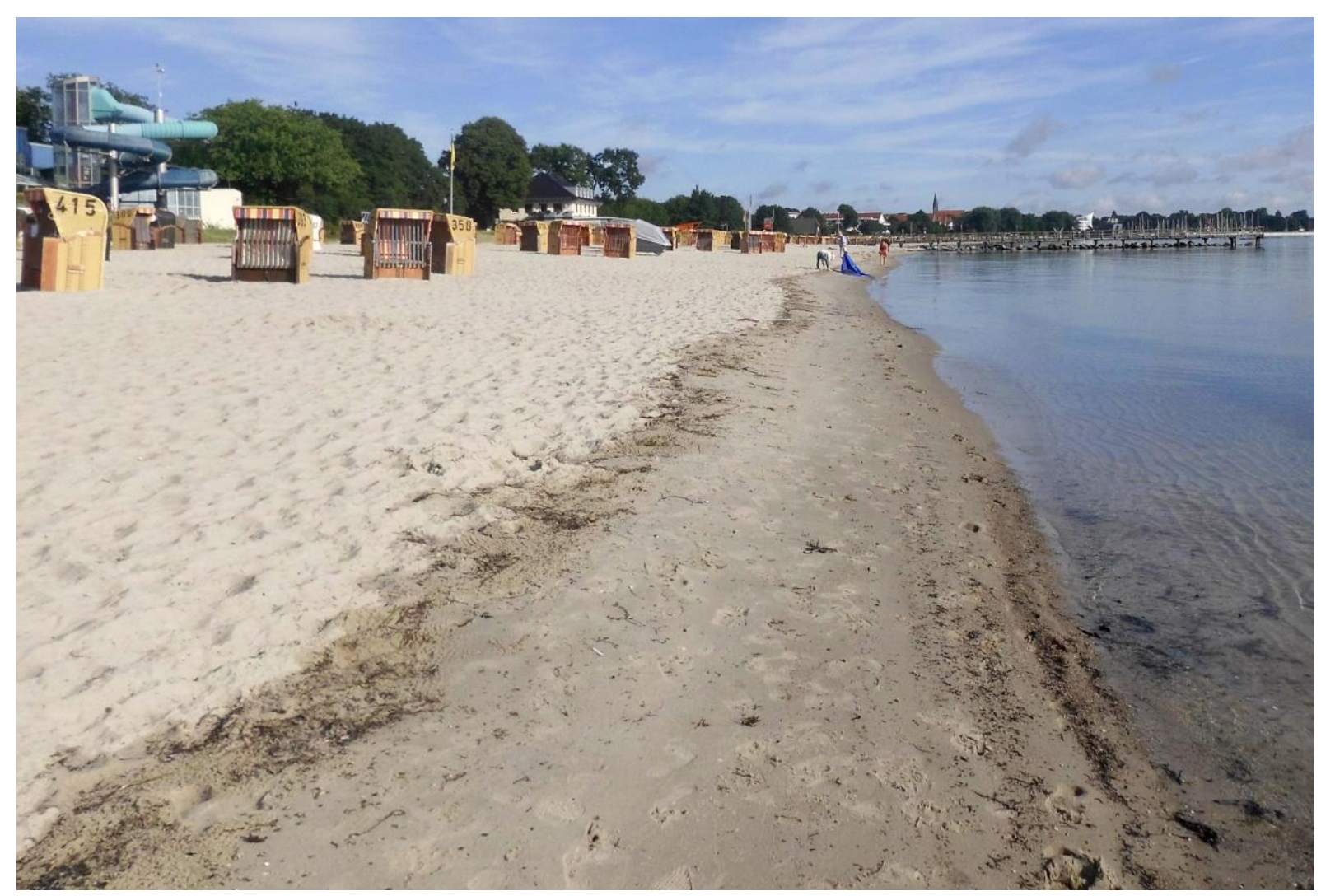


Figure S3: Minimal $\left(0 \mathrm{~g} \mathrm{~m}^{-1}\right)$ and maximal $\left(15600 \mathrm{~g} \mathrm{~m}^{-1}\right)$ densities of beach wrack tested for effects on beach visitors in experiment 2 .
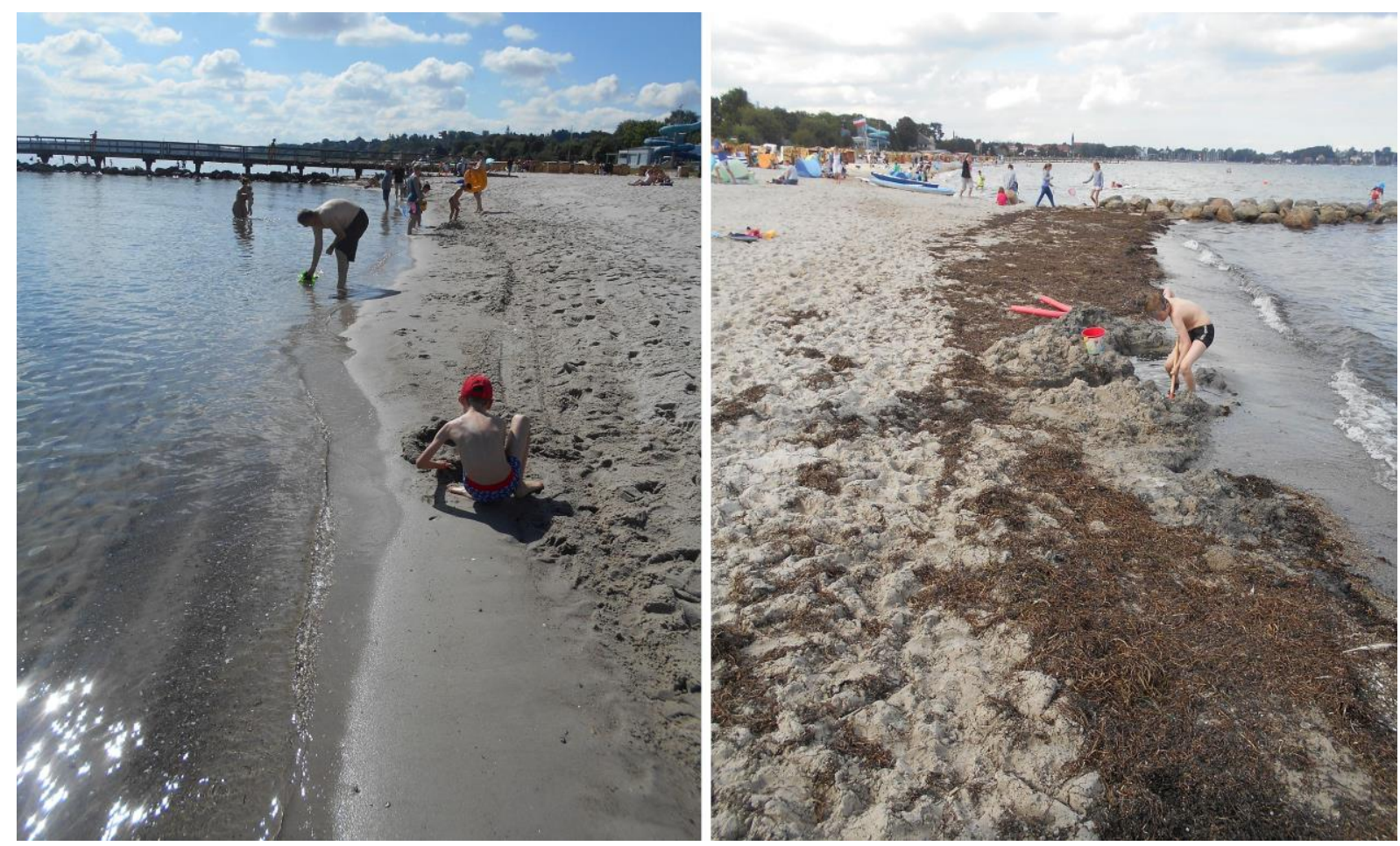
Figure S4: Effect of Zostera beach wrack density on (A.) the frequency of beach visitors crossing the beach wrack and (B.) the frequency of these visitors staying in direct vicinity of the beach wrack for 30 $\mathrm{s}$ or more time. Alltogether 118 repeated measurements were conducted during two consecutive days in time intervals of $30 \mathrm{~min}$ on six different beach sections at Eckernförde and biomass densities were determined in parallel. Lines represent best fitting linear functions (calculated in B. from the logarithmic biomass density and the non-logarithmic effect size and in A. from the double-logarithmic dataset), dotted lines indicate their $95 \%$ confidence intervals.

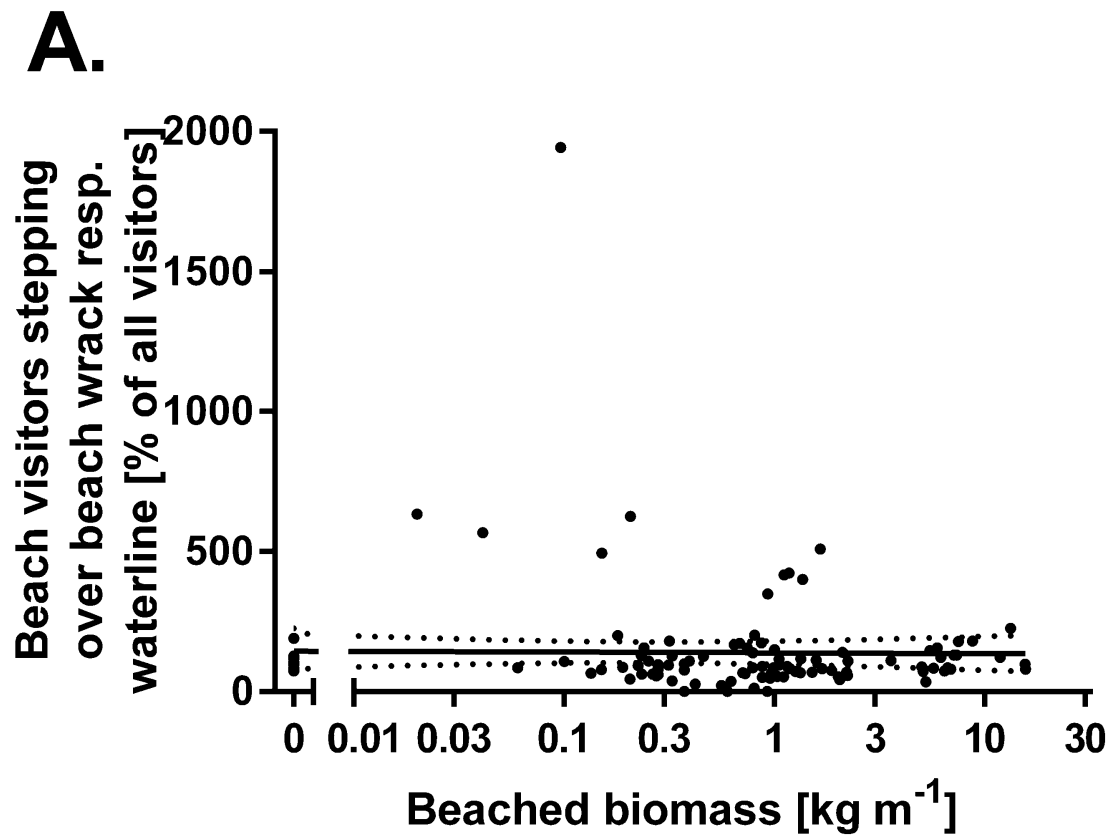

B.

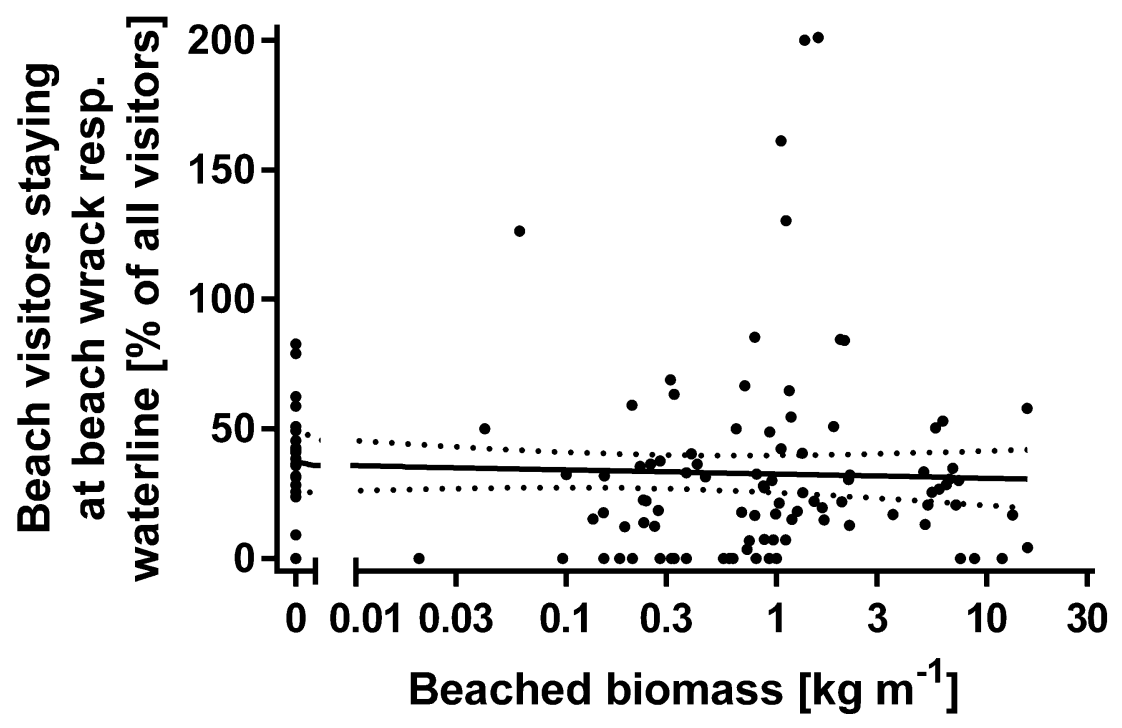

